\title{
The Relationship between the Transformational Leadership Style of Madrasah Head and Work Discipline with the Performance of Teachers at MTsN Lima Puluh Batu Bara
}

\author{
Muhammad $^{1}$, Rahmat Hidayat ${ }^{2}$ \\ ${ }^{1}$ Master Student of Islamic Education Management in FITK, UIN-SU \\ ${ }^{2}$ Lecturer in of Islamic Education Management in FITK, UIN-SU \\ muhammad10100@outlook.com
}

\begin{abstract}
This study aims to determine the magnitude of the relationship between the leadership style of madrasa principals and work discipline with the performance of teachers in MTsN Lima Puluh Batu Bara District. The sample of this research was determined by 42 people (total sampling). The data collection tool used a Likert scale questionnaire. The questionnaire was arranged based on variable indicators and examined by the Thesis Advisor, then tested on respondents who were not research samples. After testing the instrument, it is known that all $X_{1}$ instruments consisted of 37 valid items 21 items, variable $X_{2}$ consisted of 26 valid items 24 items and $Y$ consisted of 40 valid items 24 items. Test requirements for data analysis of variables $X_{1}, X_{2}$ and $Y$ are known that all variables are normally distributed, so that linearity testing and linearity test results can be found, it turns out that the regression between variables X1 with $Y$ and $X 2$ with $Y$ is also linear with $p$ values $<0.05$. Shows that: First, the transformational leadership style of madrasa principals is positively and significantly related to the performance of teachers in MTsN Lima Puluh Batu Bara District. In the research hypothesis test, obtained correlation $X_{1}$ with $Y$ of 0.379 . Second, work discipline is positively and significantly related to teacher performance in MTsN Lima Puluh Batu Bara District. In the research hypothesis test, obtained correlation $X_{2}$ with $Y$ of 0.374 . Third, the madrasa head transformational leadership style and work discipline together are positively and significantly related to the performance of teachers in MTsN Lima Puluh Madrasah, Batu Bara District. In the research hypothesis test, obtained correlation $X_{1}$ and $X_{2}$ together with $Y$ of 0.554 .
\end{abstract}

Keywords: Transformational leadership style; work discipline; teacher performance.

\section{Introduction}

Teacher performance is an important part in achieving educational goals, because a teacher in carrying out learning tasks both at school and at the madrasa is responsible for students under his guidance by increasing student learning achievement. According to Susmiati (2016: 193) explains that the teacher's performance is good if the teacher has done the elements consisting of loyalty and high commitment to the teaching task, mastering teaching materials that will be given to students.

Teacher performance is very likely to be improved. This needs to be done in an effort to achieve the goals that have been set and achieve optimal performance. For this reason, it is necessary to have a good arrangement and management by the principal (leader) of the teacher's behavior in carrying out their daily tasks. Some factors that are considered to affect performance are leadership and individual attitudes (innovative attitude), in line with the opinion of Arikunto (1994: 80) explaining that teacher performance is influenced by various factors, globally the factors that influence these are internal and external factors. Internal factors consist of: integrity, 
attitude, interest, intelligence, motivation and personality. While external factors related to leadership, facilities and infrastructure, salary, supervision, work atmosphere and work environment.

Enni Pudjiastuti (2011: 121) in her journal explained that the low performance of teachers is predicted due to many factors, both from within the individual teacher and from outside. Those that affect performance include competency, work discipline, job satisfaction, the organization where the teacher teaches, the leadership of the principal, and the existence of government policies on education. The success of organizers and management of education in schools is a reflection of competence, work discipline, job satisfaction and good performance. Suyatminah (2013: 91) explains the results of her research that transformational leadership and discipline are two factors that greatly affect performance. If both factors are owned by the teacher, it can improve teacher performance.

For this reason, scientific research needs to be done to explain transformational leadership styles and work discipline. Things that have been going on are running well, and what has not been done in the teacher performance improvement program through the effectiveness of transformational leadership and work discipline in the future. Thus the study entitled "The Relationship between the Transformational Leadership Style of Madrasah Head and Work Discipline with the Performance of Teachers in MTsN Lima Puluh Batu Bara"

\section{Literature Review}

The leadership is discussed according to the Great Indonesian Language from the basic word "lead" by getting the guidance to be "leading", which means to guide, show the way and guide in this statement can be equated with the understanding by knowing, heading, guiding and training in the art of educating and managing in 2008. In protecting subordinates, a leader must have a leadership style, according to Lahmuddin (2016: 120) "the leadership style of a leader will influence the progress and development of the organization he leads". Mulyasa (2003: 108) explains that leadership is the way used by leaders in influencing followers. Leadership style is a pattern of behavior of a typical leader when he influences his people, what is chosen by the leader to be done, the way the leader acts in influencing the group to form the leadership of his leader.

Danim (2012: 142-143) explains that the leadership of transformational schooling involves the effort to elevate people's views beyond self-interest towards joint efforts for shared goals. To transformational schools make people act on behalf of the collective importance of groups or the community of their schools. This leadership has a basis for the names of individuals and for example the achievement of the best interests and goals of the region, they are united by the head of the school in achieving higher goals, for example, the achievement of the best students in their area. In this way, the leadership of the informational madrasa has the nature of protecting, stimulating, inspiring and motivating its subordinates for better goals.

Performance is also called work performance, where the work of someone produces something that matches their ability. In the New Indonesian Language edition of the latest edition (2007: 451) "performance" is defined as: Operational / work power; Achievement shown something achieved. According to Kashmir (2016: 182) explains that it is just a simple understanding of the work performance and work performance that has been accomplished in completing the tasks and responsibilities given in certain periods. 
Teacher performance is the result obtained from the work of someone who educates, guides and directs and evaluates students to become human beings. Teacher performance or good performance is the result achieved by the teacher in carrying out the tasks assigned to him based on his expertise, then experience and sincerity in use of time. The teacher's performance will be good if the teacher has implemented the elements that have high compliance and high belief in one teacher's teaching. The performance of a teacher is seen from the extent to which the teacher takes the task with respect and is fully responsible, the ability to move and motivate students to learn from work with other teachers. Talking about teacher performance, can not be separated from the supporting factors and problem solving that causes delays in teaching and learning process well and correctly in order to achieve the expected goals in teaching in teaching. According to Kasmir (2016: 189) as for the factors that affect the performance of both results and work behavior are the ability and expertise, knowledge, work design, personality, work motivation, leadership, leadership style, organizational culture, work satisfaction, work environment, loyalty and commitment.

The term discipline is derived from the Latin language "Disciplina" which refers to learning activities and teaching, while the terminology in English is "Disciple" which means to follow a person to learn under the supervision of a leader "(Tu'u, 2004: 30). Discipline is "something like how people who are incorporated in an organization are subject to the rules that have been filled with pleasure" (Imron, 1995: 182).

Work discipline is one of the factors that can affect the productivity of work, while productivity is the success of an organization. Thus there is a link between work discipline and productivity. Being disciplined is one of the determinants of success or not organizational goals. Discipline is defined as the implementation of management to strengthen organizational guidelines "(Mangkunegara, 2002: 129).

\section{Research Methods}

The research was conducted at MTsN Lima Puluh Batu Bara District on Jalan MedanLimaPuluh. The selection of this place is based on consideration of the ease of obtaining data because its location is only $0.5 \mathrm{~km}$ from the place of researchers working in MAN Lima Puluh, while this research was conducted in January to April 2018.

Judging from the type of research to be collected, this research is classified as quantitative research with a correlation approach or causal (causal) relationship. This method is referred to as the scientific method because it meets the scientific principles of concrete / empirical, objective, measurable, rational and systematic. This method is called quantitative because this research data in the form of numbers and analysis using statistics (Sugiyono, 2014: 13). Namely research data in the form of numbers and numbers, then arranged, arranged and presented in the form of a list, table or graph.

Arikunto (2006: 120) argues that "for the mere threat of the subject matter is less than a hundred, then it is better to take it all, so that the research is a population research. Furthermore, if the subject is large, it can be taken between $10 \%, 15 \%$ or $20 \%, 25 \%$ or more ". Noting the above statements, because the number of population (teachers) was less than 100 people, then the total population of the study was made as a sample (total sampling) in which there were 42 people.

Research data collected from respondents were processed and analyzed with descriptive and imperative statistical techniques. Descriptive statistical techniques are used to determine the 
mean, standard deviation, mode, median, histogram and propensity test. Whereas the imperative statistic uses simple correlation and multiple correlation and partial correlation which is preceded by test data analysis requirements.

\section{Discussion}

From the analysis of the description it was found that in general the transformational leadership style of madrasas heads in MTsN Lima Puluh in Batu Bara District was in the medium category, work discipline in MTsN Lima Puluh in Batu Bara District was in the high category, and the performance of teachers in the MTsN Lima Puluh in Batu Bara District was in the moderate category.

From a simple correlation analysis and a partial correlation it was found that a positive and significant relationship between the madrasa head transformational leadership style variables and the performance of MTsN Lima Puluh teachers in Batu Bara District. This can be seen from the large simple correlation between $\mathrm{X}_{1}$ and $\mathrm{Y}\left(\mathrm{rX}_{1} \mathrm{Y}\right)=0.379$. This result was consulted with rtable with $\mathrm{N}=42$ at a significance level of $5 \%=0.304$. With $\mathrm{rX}_{1} \mathrm{Y}=0.379$, it is obtained tcount $=2.586$. This result was consulted with a table with $\mathrm{N}=42$ at a significance level of $5 \%=1.68$. Then from the results of calculations with partial correlation obtained ry, $2.1=0.376$. This result was consulted with rtable with $\mathrm{N}=42$ at a significance level of $5 \%=0.304$. With ry, $2.1=0.376$ is obtained tcount $=2.531$. This result was consulted with a table with $\mathrm{N}=42$ at a significance level of $5 \%=1.68$. Thus the research hypothesis proposed that there is a positive and meaningful relationship between the madrasa head transformational leadership style with the performance of MTsN Lima Puluh teachers in Batu Bara District can be accepted and tested for truth. Thus work discipline contributes $14.36 \%$ to teacher performance.

Also found a positive and meaningful relationship between work disciplines with teacher performance. This can be seen from the large simple correlation between $\mathrm{X}_{2}$ and $\mathrm{Y}\left(\mathrm{rX}_{2} \mathrm{Y}\right)=$ 0.374. This result was consulted with rtable with $\mathrm{N}=42$ at a significance level of $5 \%=0.304$. With the price of $\mathrm{rX}_{2} \mathrm{Y}=0.374$, it is obtained tcount $=2.552$. This result was consulted with a table with $\mathrm{N}=42$ at a significance level of $5 \%=1.68$. Then from the results of calculations with partial correlation obtained ry, $1.2=0.371$. This result was consulted with rtable with $\mathrm{N}=42$ at a significance level of $5 \%=0.304$. With the price of ry, $1.2=0.371$, obtained tcount $=2.497$. This result was consulted with a table with $\mathrm{N}=42$ at a significance level of $5 \%=1.68$. Thus the research hypothesis proposed that there is a positive and meaningful relationship between work discipline and the performance of MTsN Lima Puluh teachers in Batu Bara District can be accepted and tested for truth. Thus work discipline contributes $16.5 \%$ to teacher performance.

In addition, a positive and significant relationship was found between the madrasa head transformational leadership style and work discipline with the performance of MTsN Lima Puluh Batubara District teachers with a correlation coefficient Ry (1.2) $=0.554$; while rtable with $\mathrm{N}=42$ and a significance level of $5 \%$ is 0.304 . Thus the price of $\mathrm{R}_{\text {count }}>\mathrm{r}_{\text {table }}(0.554>0.304)$. Then the significance of the correlation test is performed using the F-test. With $\mathrm{R}_{\text {count }}=0.554$ obtained $\mathrm{F}_{\text {count }}=8.638$. The $\mathrm{F}$ table price for $\mathrm{N}=42$ at the $5 \%$ significance level is 3.23. Because $F_{\text {count }}>F_{\text {table }}(8,638>3.23)$, it can be said that the research hypothesis proposed is that there is a positive and meaningful relationship between the madrasa head transformational leadership style and work discipline with the performance of MTsN Lima Puluh teachers in Batu Bara District. . Thus the madrasa head's transformational leadership style and work discipline contribute $30.70 \%$ to teacher performance, and the rest is determined by other circumstances. 
In the study it was found that the performance of MTsN Lima Puluh teachers in Batu Bara District was included in the medium category. For this reason, efforts should be made to improve the performance of MTsN Lima Puluh Batu Bara District teachers. Of the 42 respondents surveyed, found 14 people $(33.333 \%)$ in the low category, 22 people $(52.381 \%)$ in the medium category, and 6 people $(14.286 \%)$ in the high category. This information shows that the performance of MTsN Lima Puluh, Batu Bara district teachers must still be improved. The performance of MTsN Lima Puluh teachers in Batu Bara District must continue to be improved, considering that teacher competencies are needed in teaching. This is stated in the Law on Teachers and Lecturers No. 14 of 2005 Article 5 that the position of teachers as professionals serves to improve the dignity and role of teachers as agents of learning, developers of science, technology, and arts and community service functions to improve the quality of national education. In this case, teachers are required to have knowledge and the ability to provide knowledge to students. The better the teacher's competence in teaching, will give better results for students' knowledge / skills. Some factors that are thought to provide an increase in the performance of the Lima Puluh MTsN Teachers in Batu Bara District include the transformational leadership style of madrasas and work discipline. The better the transformational leadership style of madrasas and work discipline, will improve teacher performance.

Based on the results of the analysis conducted showed that the style of transformational leadership in madrasas is related and gives to the performance of the teachers of MTsN Lima Puluh District Coal is a work discipline. This is due to the head of the madrasa being the leader or leader in the madrasa. As a leader the principal has the duty to mobilize all the resources that exist in the madrasa so that it can be utilized optimally to achieve the goals set. Whether or not the performance of teachers in madrasas is very dependent on how the ability of principals to influence the behavior of teachers in carrying out their duties because according to Pidarta (1988: 177) in carrying out their duties teachers tend to submit to the principal so that everything that is carried out by teachers must refer to policies from the principal. In addition, if deviations occur in the implementation of the policy, the school principal has the right to reprimand and give warnings.

The results of this study support the results of research conducted by Agustiar, et al (2005) stating that leadership practices affect the performance of PPNS investigators. Irawati and Bambang (2010) in a study stated that the influence of leadership style on performance. Leaders are said to be unsuccessful if they cannot motivate, move and satisfy employees in a particular work and environment. The leader's job is to encourage subordinates to have competence and opportunities to develop in anticipating every challenge and opportunity at work.

Sallis (2006: 170) states that leadership really determines quality, without good leadership the process of improving quality cannot be done and realized. In madrassas, the decision-making policy rests with the madrasa head. As a leader, the principal can do various things in an effort to improve teacher performance. The virtue of leadership influences are not merely in the form of instructions, but rather are motivations or triggers that can inspire teachers and teachers, so that their initiative and creativity develop optimally to improve their performance (Yuniarsih and Suwatno, 2008: 166). Without the leadership of madrasa organizations will not be achieved and will cause chaos because each person works to achieve his personal goals.

Transformational leadership style shown by madrasah head in explaining their duties will make madrasa head as a good supervisor, besides madrasah head will also have emotional stability when facing any problems that arise, have the ability to take every decision firmly, have 
good communication skills, and have good social relations skills with the teacher. From these results it shows that in addition to being task oriented, the principal of the MTsN Lima Puluh Batu Bara District in leading his institution also prioritizes the establishment of harmonious relations with subordinates in this case is the teacher. The necessity of applying the transformational leadership style in madrasah is more due to the consideration that the success of education in madrasah is actually a collective effort of all school members. Being aware of this, the application of the transformational leadership style by the madrasa head encouraged the involvement of all madrasah citizens to be equally involved in determining the success and progress of the madrasah.

The results of this study are in line with the opinion of Danim (2012: 142-143) who explains that the leadership of transformational principals involves efforts to lift people's views beyond self-interest towards joint efforts for common goals. Transformational school principals make people act on behalf of the collective interests of their school group or community. This leadership has the basic reason that although individuals may have separate interests and goals, they are all united by the headmaster in achieving higher goals, for example, the best student learning outcomes in his area. Thus that the madrasa head's transformational leadership style has the nature to nurture, stimulate, inspire and motivate his subordinates for a better goal. Sofyan Lubis (2016) also confirms that there is a positive and significant relationship between teacher perceptions about head leadership and the performance of the madrasah teacher with the results of the coefficient determination $(\mathrm{r} 2 \mathrm{y} 1=0.395)$ can be interpreted by the variable $39.5 \%$ of the teacher's performance which is determined by the teacher's perception of the principal's leadership. Susmiati's research (2016), which concluded that there is a positive influence between madrasah head transformational leadership on teacher performance in All MAN Tulungagung Districts is shown from the positive beta value $(\beta=+0.242)$ and is significant, supported by $t_{\text {count }}$ greater than $t_{\text {table }}(2.743>0.677)$ and $P_{\text {count }}$ is smaller than the probability value of 0.05 or $(0.007$ <0.05). Likewise with the research results of Intan Silvana Maris, et al (2016), which concluded that teacher performance $\left(\mathrm{X}_{2}\right)$ together on school quality $(\mathrm{Y})$ was $52.1 \%$ and the remaining 47.9\% was influenced by other factors. Tri Setijo Harijanti's (2013) study found that there was a significant relationship between madrasah head transformational leadership and teacher performance in a positive direction, and Boiman's research (2013), which concluded that perceptions about transformational leadership had a positive and significant relationship with teacher involvement and contribution to the contribution of $21.23 \%$.

The results of this study also indicate that there is a positive and significant relationship between work discipline and MTsN Lima Puluh teacher performance in Batu Bara District where work discipline contributes $16.5 \%$ to teacher performance and this magnitude is greater when compared to the transformational leadership style of the madrasah head.

Hasibuan (2005: 194) explains that work discipline is the awareness and willingness of a person to obey company regulations and applicable social norms. The same thing was expressed by Gouzali (2006: 111), that work discipline is interpreted as an attitude and behavior of an employee which is manifested in the form of an employee's willingness to be aware, and sincerity sincerity or without coercion to obey and implement all company regulations and policies in in carrying out its duties and responsibilities in an effort to contribute to the maximum achievement of company goals.

Colquit, Lepine, and Wesson (2009: 8) in the form of a model called the Integrative Model of Organization Behavior confirms that individual outcomes that are considered to influence organizational performance and commitment behavior consist of: job satisfaction, 
stress, motivation, trustworthiness, fairness and ethics, as well as learning and decision making. Meanwhile, individual mechanisms are influenced by organizational mechanisms consisting of, organizational culture and organizational structure, group mechanisms, which consist of leadership styles and behaviors, leadership power and influence, team processes, team characteristics, and individual characteristics, consisting of: personality and cultural values and abilities.

Based on the above model, it is shown that performance behavior is reflected in obedience, submission and compliance respecting applicable regulations, this behavior is commonly known as work discipline. Susilo (2007: 116) also mentions that factors that influence employee work discipline include motivation, education and training, leadership, welfare and discipline enforcement.

Meanwhile this study also shows that there is a positive and meaningful relationship between the madrasa head's transformational leadership style and Work Discipline together with the performance of MTsN Lima Puluh Batubara District teachers, both of which contribute $30.70 \%$ to teacher performance, and the rest is determined by other circumstances.

\section{Conclusion}

There is a significant and significant relationship between the madrasah's head transformational leadership style and teacher performance in MTsN Lima Puluh Batu Bara District, meaning that the better the madrasa head transformational leadership style the better the teacher's performance in MTsN Lima Puluh Batu Bara District. There is a significant and significant relationship between work discipline and teacher performance in MTsN Lima Puluh Batu Bara District, meaning that the better the work discipline is, the better the teacher's performance at MTsN Lima Puluh Batu Bara District. There is a significant and significant relationship between the madrasa head transformational leadership style and work discipline with teacher performance in MTsN Lima Puluh Batu Bara District, meaning that the better the madrasah head transformational leadership style and work discipline, the better the teacher performance in MTsN Lima Puluh District Coal.

\section{References}

Alwi, Hasan. (2008). Kamus Besar Bahasa Indonesia,Jakarta: Balai Pustaka.

Arikunto, Suharsimi. (1990). Manajemen Pengajaran Secara Manusiawi, Jakarta: Rineka Cipta

Boiman. (2013). Hubungan Persepsi Tentang Kepemimpinan Transformasional Kepala Madrasah dan Sikap Inovatif dengan Kinerja Guru SMP di Kecamatan Talawi KabupatenBatu Bara. Thesis. Medan: PPSUINSU.

Danim, Sudarman. (2012). Kepemimpinan Pendidikan (Kepemimpinan Jenius (IQ + EQ), Etika, Perilaku Motivasional dan Mitos). Bandung: Albeta.

Harijanti, Tri Setijo. (2013). Hubungan Kepemimpinan Transformasional Kepala Sekolah dan Motivasi Berprestasi dengan Kinerja Guru SD di Kecamatan Bandungan. Thesis. Salatiga: PPSUKSW.

Hasibuan, Malayu S.P. (2016). Manajemen sumber daya manusia. Jakarta: Bumi Aksara.

Imron, Ali. (1995). Pembinaan Guru di Indonesia. Jakarta: Pustaka Jaya.

Kasmir. (2016). Manajemen sumber daya manusia (Teori dan Praktik). Jakarta: Raja Grafindo Persada.

Lubis, Lahmuddin. (2016). Konseling dan Terapi Islam. Medan: Perdana Publishing.

Mangkunegara, Anwar Prabu. (2017). Manajemen sumber daya manusia Perusahaan. Bandung: Remaja Rosda karya. 
Maris, Intan Silvana, et al. (2016). Kepemimpinan Transformasional Kepala Sekolah, Kinerja Guru dan Mutu Sekolah. Journal of Administrasi Pendidikan.Vol. XXIII, No.2.

Mulyasa. (2003). Manajemen Berbasis sekolah (Konsep, Strategi dan Implementasi). Bandung: Remaja Rosdakarya.

Pudjiastuti, Enni. (2011). Pengaruh Kompetensi, Disiplin Kerja dan Kepuasan Kerja terhadap Kinerja Guru SMP Negeri 1 Purwodadi Grobogan. Journal of Manajemen sumber daya manusia. Vol.5, No.2.

SofyanLubis, Ahmad. (2016). Hubungan Persepsi Guru tentang Kepemimpinan Kepala Madrasah dan Motivasi Kerja Guru dengan Kinerja Guru Madrasah Tsanawiyah Swasta al-Washliyah Tembung Kecamatan Percut Sei Tuan Kabupaten Deli Serdang. Thesis. Medan: PPSUINSU.

Suyatminah. (2013). Peran Kepemimpinan Transformasional dan Kedisiplinan terhadap Kinerja Guru TK PNS Se-Kecamatan Bantul. Journal of Bimbingan dan Konseling FKID UAD.Vol.2, No.2.

Tu'u Tulus. (2004). Peran Disiplin Pada Perilaku Dan Prestasi Siswa,Jakarta: Grasindo, Undang-Undang Republik Indonesia Nomor 14 tahun 2005 tentang Guru dan Dosen.

Wibowo. (2014). Manajemen Kinerja. Jakarta: Raja Grafindo Persada. 